\title{
Cikkismertetés: A mentális jóllét és az elhízás kapcsolata
}

\author{
Article review: The relationship between mental well-being and obesity \\ Ismertető: $\quad$ Devosa Iván $\square$ \\ Károli Gáspár Református Egyetem, Tanitóképző Főiskolai Kar, Egészségtudományi \\ Kutatómühely, Kecskemét
}

Ismertetett cikk: Rand K., Vallis M., Aston M., et al.: "It is not the diet; it is the mental part we need help with." A multilevel analysis of psychological, emotional, and social well-being in obesity, International Journal of Qualitative Studies on Health and Well-being (2017), 12:1, https://doi.org/10.1080/17482631.2017.1306421

Beküldve: $\quad$ 2020. 10. 25.

doi: $\quad$ 10.24365/ef.v61i4.649

Kulcsszavak: elhízás; túlsúly; jóllét; mentális jóllét; társadalmi-ökológiai modell

Keywords: obesity; overweight; well-being; mental well-being; Socio-Ecological Model (SEM)

\section{HÁTTÉR}

Az eredeti kutatás irányadó módszertana a feminista posztstrukturalizmus volt. Ennek oka, hogy a feminista posztstrukturalizmus arra összpontosít, hogy a személyes tapasztalatok, attitúdök milyen társadalmi és intézményi hatásokon keresztül alakulnak ki, illetve a diskurzusok és a hatalmi viszonyok hogyan változtatják meg az egyén saját véleményét. Jelen kutatás célja, hogy a kutatók megismerjék az elhízással élók pszichológiai, érzelmi és társadalmi tapasztalatait, valamint az egészségügyi szakemberek (dietetikusok, háziorvosok, ápolók) ezzel kapcsolatos nézeteit, véleményeit.

\section{MÓDSZER}

A kelet-kanadai elhízással élő egyének (19 fő) és szakemberek (16 fő) körében, 2010 és 2011 között lefolytatott kvalitatív interjúk felhasználásával készült kutatásban, az adatelemzéshez két elméleti keretrendszert (1. és 2. táblázat) alkalmaztak a kutatók, amelyeket egy korábbi tanulmány alapján dolgoztak ki. A mentális jólléti keretrendszer témáit ezt követően a társadalmi-ökológiai modell (Social-
Ecological Model, továbbiakban SEM) öt környezeti szintje alá sorolták. A legfontosabb mentális jólléti témák megjelentek a SEM minden szintjén, kivéve a szakpolitikai szintet.

Először a mentális jóllét keretrendszert a WHO fejlesztette ki (2005-ben), mely koncepció szerint a teljes mentális jóllét elengedhetetlen az egészség eléréséhez: a 1. táblázat bemutatja a WHO meghatározása alapján a pszichológiai, érzelmi és szociális területeken a fő mentális szükségleteket a jóllét eléréséhez.

A második elméleti keretrendszer [2. táblázat], a társadalmi-ökológiai modell (Social-Ecological Model - SEM) volt, melyet a mentális jóllét azonosított témáinak kategorizálására alkalmaztak a szerzők. A SEM egy elmélet alapú keretrendszer, mely segít megérteni, hogyan befolyásolja az egyéni viselkedést a társadalmi rendszer által kialakított környezet.

A SEM keretrendszer használata ebben a konkrét kutatásban lehetővé tette, hogy meghatározzák, az elhízással élő egyének hol és milyen a közérzetüket hátrányosan befolyásoló élményeket tapasztalnak. 
1. táblázat: A mentális jóllét érzelmi, pszichológiai, társadalmi területei

Az érzelmi jóllét dimenziói

Pszichológiai jóllét dimenziói

Társadalmi jóllét dimenziói

\begin{tabular}{|l|l|l|}
\hline Pozitív hatás & Önelfogadás & Társadalmi integráció \\
\hline Negatív hatás & Pozitív kapcsolat másokkal & Társadalmi elfogadottság \\
\hline Boldogság & Autonómia & Társadalmi hozzájárulás \\
\hline Élettel való elégedettség & A környezetünk megértése és dominálása & Társadalmi aktualizáció \\
\hline & Életcél & Társadalmi koherencia \\
\hline & Személyes fejlődés & \\
\hline
\end{tabular}

Forrás: saját szerkesztés az eredeti változat alapján

2. táblázat: A mentális jóllét feltárása a SEM modell alkalmazásával

\begin{tabular}{|l|l|}
\hline \multicolumn{1}{|c|}{$\begin{array}{l}\text { A társadalmi-ökológiai modell } \\
\text { (SEM) szintjei }\end{array}$} & \multicolumn{1}{c|}{ Kapcsolat a mentális jólléttel } \\
\hline Egyéni & $\begin{array}{l}\text { Az elhízás hogyan befolyásolja a mentális jóllétet és az önelfogadást. } \\
\text { befolyásolja a mentális jóllétet. }\end{array}$ \\
\hline Interperszonális & $\begin{array}{l}\text { A résztvevő́k kapcsolatai az egészségügyi rendszerrel, összefüggésben a mentá- } \\
\text { lis jólléttel kapcsolatos aggodalmaikkal. }\end{array}$ \\
\hline Szervezeti & $\begin{array}{l}\text { Az elhízással élők közösségi kapcsolatai milyen hatást gyakorolnak a mentális jól- } \\
\text { létükre. }\end{array}$ \\
\hline Közösségi & $\begin{array}{l}\text { A résztvevők tudatossága a mentális jóllét támogatására vonatható politikákról, } \\
\text { ha vannak ilyenek. }\end{array}$ \\
\hline Politikai &
\end{tabular}

Forrás: saját szerkesztés az eredeti változat alapján

\section{EREDMÉNYEK}

A SEM egyéni szintjén belül, az egyik azonosított probléma az élelmiszer volt, mint a megküzdési mechanizmus része és egyben az érzelmi szorongás forrása. Az élelmiszer fogyasztása önmagában, mint menekülési út vagy más stresszorokkal való megküzdési eszköz előidéz egy másodlagos stresszort, amikor a résztvevők felfedezték, összekapcsolták az étkezési szokásaikat az érzelmi jóllétüket befolyásoló mentális szorongás enyhítésével, illetve amikor a szorongás azért alakul ki, mert az elfogyasztott élelmiszerek mennyisége és fajtája maga lett a szorongás forrása. Az interperszonális szinten két problémaforrás volt: a családtagok és a barátok általi hibáztatás és szégyen (pl: bántó megjegyzések miatt) a túlsúlyból adódóan, illetve az egészségügyi szakemberek támogató attitǔdjének a hiánya: a külső megjelenés miatti szégyen az egyik oka annak, hogy kevésbé vesznek részt a közösségi életben. Az elhízással élő egyének társadalmi jóllétére gyakorolt negatív hatás nyilvánvaló volt azok számára, akik maguk is megtapasztalták az elítélő megjegyzésket. A szervezeti szinten az egyik fő gond a testsúlycsökkentő programok mentális jólléti problémáinak nem megfelelő támogatása volt. A közösségi szint egyik fő problémája az elhízás miatti társadalmi megbélyegzés negatív hatása a mentális jóllétre. A testsúly miatti megbélyegzés és elfogultság aspektusa tovább alakította a társadalmi-ökológiai modell (SEM) minden szintjén a domináns kérdéseket.

\section{KÖVETKEZTETÉSEK}

Az elhízással élő egyének a testsúlyuk miatt szembesülnek a mentális jóllétüket befolyásoló negatív 
hatásokkal a környezetük (SEM) több szintjén. Az eredmények alapján: az élelmiszer, mint megküzdési mechanizmus és az érzelmi szorongás forrása jelent meg; hibáztatás és szégyen az interperszonális kapcsolatokban; elítélés és a pszichoszociális ellátás hiánya az egészségügyi rendszeren belül; emellett az elhízás társadalmi megbélyegzésének negatív hatása. Az elhízással élőkkel szembeni, súlyukkal kapcsolatos elfogultság a résztvevők mentális jóllétének romlását okozó negatív kölcsönhatások fő forrása volt, amint azt korábbi tanulmányaikban már ismertették a kutatók. Míg az egészségügyi szolgáltatók képesek azonosítani az SEM egyéni és szervezeti szintű kérdéseit, és feltárni mi akadályozza a pozitív mentális jóllétét a betegeik- nek, ugyanakkor nem ismerik fel az egészség társadalmi meghatározóit, vagy annak szükségességét, hogy túllépjenek az egyéni egészségügyi modellen, ezzel is támogatva betegeiket. A feltárt adatoknak arra kell ösztönözniük az egészségügyi szakembereket és a politikai döntéshozókat, hogy a mentális jóllét jobb kezelése érdekében újraértékeljék az elhízás kezelési stratégiáikat és az elhízással kapcsolatos szakpolitikájukat. Amíg nem ismerik el, és tesznek jelentős erőfeszítéseket azért, hogy csökkentsék az elhízással élők irányában az elfogultságot az egészségügyi szervezeteknél és a társadalomban egyaránt, nem lesznek képesek biztosítani megfelelően a mentális jóllét támogatását elhízással élőknek.

\section{TANULSÁGOK A HAZAI SZAKEMBEREK SZÁMÁRA}

Magyarországon is egyre jelentősebb egészségügyi probléma a túlsúly és az elhízás, mely megjelenik mind egyéni, mind magasabb szinteken (SEM). A szakemberek felhasználhatják a tanulmányban szereplő információkat arra, hogy olyan elhízás kezelési (testsúlycsökkentési) programokat és szakpolitikákat dolgozzanak ki, melyekben azokra a környezeti változásokra is összpontosítanak, amelyek aktívan elősegítik a pozitív mentális jóllét létrejöttét és fenntartását. 